\title{
PENGENTASAN KEMISKINAN MELALUI PENDEKATAN WAKAF TUNAI
}

\author{
Rudy Haryanto \\ (Jurusan Syari'ah STA IN Pamekasan, JI. Raya Panglegur KM . 04 Pamekasan, \\ email: Rudyharyanto76@yahoo.co.id)
}

\begin{abstract}
A bstrak:
Kemiskinan merupakan masalah kompleks yang dihadapi bangsa ini, dan ternyata tidak mudah untuk diatasi. Penanggulangan kemiskinan memerlukan pemahaman mengenai dimensi dan pengukuran kemiskinan yang operasional sehingga menghasilkan strategi yang tepat. Strategi tersebut harus menyentuh pendekatan ekonomi mikro dan makro, langsung dan tidak langsung, yang dilakukan secara simultan dan berkelanjutan, dan hal ini dapat dilakukan apabila kita bisa memberdayakan wakaf tunai. Wakaf tunai bertujuan menghimpun dana abadi yang bersumber dari umat, yang kemudian dapat dimanfaatkan bagi sebesar-besarnya kepentingan dakwah dan masyarakat. Dana wakaf yang terkumpul ini selanjutnya dapat digulirkan dan diinvestasikan oleh nadzir ke dalam berbagai sektor usaha yang halal dan produktif, sehingga keuntungannya dapat dimanfaatkan untuk pembangunan umat dan bangsa secara keseluruhan.
\end{abstract}

\begin{abstract}
A bstract:
The poverty is a complex problem faced by this country, and it is not easy to solve. The solution of poverty needs the understanding concerning the dimension and the operational measurement to make a correct strategy. This strategy must use the approach of micro and macro economy, direcly and indirectly, done simultaneously and continously. It can be done if we are able to empower the donation cash. Its purpose to collect the eternal fund from the people, then it can be used maximally for the interest of religious speech and society. The donation fund which is collected can be given and invested by nadzir to any sectors of business that are rightful and productive in order to make its profit advantageous to the people development and nation for the whole.
\end{abstract}


Pengentasan Kemiskinan

Kata-kata Kunci:

Kemiskinan, neo-klasik, sosial liberal, wakaf tunai, dan ekonomi mikro-makro

\section{Pendahuluan}

"Wakaf tunai sebagai jembatan emas antara si kaya dan si miskin." 1 Kemiskinan pada hakekatnya merupakan persoalan klasik yang telah ada sejak umat manusia ada. Kemiskinan merupakan persoalan kompleks, dan tampaknya akan terus menjadi persoalan aktual dari masa ke masa. ${ }^{2}$ Kompleksitas masalah kemiskinan dikarenakan kemiskinan termasuk dalam masalah ekonomi. Dalam ilmu ekonomi membahas segi pertumbuhan, maka pasti hal itu akan menyinggung soal-soal kemiskinan. Karena tingkat kemiskinan berkaitan dengan tingkat pertumbuhan ekonomi.

Meskipun sampai saat ini belum ditemukan suatu rumusan maupun formula penanganan kemiskinan yang dianggap paling jitu dan sempurna, namun penemu-kenalan konsep dan strategi penanganan kemiskinan harus terus menerus diupayakan. Kemiskinan ini harus dilihat sebagai malapetaka kemanusiaan yang amat tragis dan merupakan fakta sosial yang nyaris absolut di Indonesia. Untuk itu pengentasan kemiskinan merupakan tantangan global terbesar yang harus dihadapi, karena menjadi syarat mutlak bagi pembangunan berkelanjutan.

Berbagai upaya telah dilakukan, beragam kebijakan dan program telah disebar-terapkan, berjumlah dana telah dikeluarkan demi menanggulangi kemiskinan. Tak terhitung berapa kajian dan ulasan telah dilakukan. Untuk itu, sebagai basis komunitas muslim terbesar, kita sudah sepatutnya menciptakan kebijakan sendiri untuk keluar dari jebakan ekonomi global Barat. ${ }^{3}$

Mengembangkan ekonomi syarî'ah dengan sumber dana wakaf tunai menjadi pilihan yang terbaik untuk mengatasi

\footnotetext{
1 Slogan di atas dikutip dari Departemen Agama RI, Pedoman Pengelolaan W akaf Tunai, (Jakarta: Direktorat Pemberdayaan Wakaf Direktorat Jenderal Bimbingan Masyaratat Islam, 2007)

2 Dawam Rahardjo, Kemiskinan Sebagai M asalah Ekonomi, Dalam Esei-Esei Ekonomi P olitik, (Jakarta: LP3S, 1983), hlm. 15

3 Achmad Djunaidi dan Thobieb al-Asyiar, M enuju Era Wakaf Produktif, Jakarta: Mumtaz Publishing, 2007), hlm. 5
} 
Rudy Haryanto

kemiskinan. ${ }^{4}$ Sesungguhnya, telah banyak solusi yang ditawarkan para praktisi dan akademisi ekonomi syarî'ah. Solusi tersebut antara lain melalui penerbitan sukuk. Meskipun sukuk sendiri pada hakikatnya mirip dengan utang, namun ia memiliki bentuk yang berbeda dengan utang konvensional. Sukuk haruslah berbasis aset dan proyek di sektor riil, sedangkan utang konvensional tidak mewajibkannya. Bahkan sebaliknya, undang-undang melarang pemerintah menerbitkan SUN yang berbasis aset .Sehingga ,sukuk dapat memberikan lebih banyak manfaat dalam menciptakan lapangan kerja karena dana yang terserap akan benar-benar digunakan pada sektor riil dan tidak bisa digunakan untuk spekulasi di pasar uang.

Solusi pengentasan kemiskinan dengan cara menggali sumber dana melalui wakaf tunai harus mulai kita kampanyekan secara lebih intensif. Inilah sebenarnya 'raksasa' yang jika bangkit, perekonomian nasional bakal segera menggeliat dan memerdekakan dirinya dari belenggu kapitalisme global. Sejak awal harus di sadari bahwa wakaf, tidak terkecuali wakaf tunai merupakan dana public. Karena dana wakaf dihimpun dari masyarakat luas yang dengan suka rela menyisihkan hartanya untuk diwakafkan. Disbanding dengan instrument keuangan lain dalam system ekonomi Islam, maka dana wakaf tampak fleksibel untuk digunakan sebagai sarana pemberdayaan terhadap umat Islam. ${ }^{5}$

Payung hukum wakaf tunai di Indonesia telah dilegitimasi oleh MUI melalui fatwanya pada pertengahan Mei 2002 dan UU No 41 Tahun 2004. Wakaf tunai bagi umat islam Indonesia memang masih relatif baru. Konsep wakaf yang masih terbatas pada persoalan tanah dan bangunan (benda tak bergerak) harus di-up grade dengan konsep wakaf tunai (benda yang bergerak), yang manfaatnya untuk kepentingan pendidikan, riset, rumah sakit, pemberdayaan ekonomi lemah dan lain-lain.

Selanjutnya untuk lebih memahamkan kepada masyarakat tentang konsep wakaf tunai, dipaparkan manfaat utama dari wakaf tunai: Pertama, wakaf tunai jumlahnya bisa bervariasi sehingga

4 Muhammad A hmad Khalafallah, M asyarakat M uslim Ideal, Jakarta: Insan Madani, 2008), hlm. 105

5 Departemen A gama RI, P edoman Pengelolaan, hIm. 50 
seseorang yang memiliki dana terbatas sudah bias mulai memberikan dana wakafnya tanpa harus menunggu menjadi tuan tanah terlebih dahulu. Kedua, melalui wakaf tunai, asset-aset wakaf yang berupa tanah-tanah kosong bias mulai dimanfaatkandengan pembangunan gedung atau diolah untuk lahan pertanian. Ketiga, dana wakaf tunai juga bisa membantu sebagian lembaga-lembaga pendidikan islam yang cash flow-nya terkadang kembang kempis dan menggaji civitas akademika ala kadarnya. Keempat, umat Islam dapat lebih mandiri dalam mengembangkan dunia pendidikan tanpa harus tergantung pada anggaran pendidikan negara yang memang semakin lama semakin terbatas. ${ }^{6}$

Kemiskinan merupakan masalah sosial yang senantiasa hadir di tengah-tengah masyarakat, khususnya di negara-negara berkembang seperti Indonesia ini. Kemiskinan senantiasa menarik perhatian berbagai kalangan, baik para akademisi maupun praktisi. Berbagai teori, konsep dan pendekatan pun sudah seharusnya dikembangkan untuk menyibak tabir "misteri" kemiskinan ini.7 Kita sudah harus mulai belajar banyak mengenai implementasi wakaf tunai sebagai solusi pengentasan kemiskinan ${ }^{8}$ kepada negara-negara yang telah mengaplikasikan wakaf tunai.

\section{Mengurai Konsep Kemiskinan}

Konsepsi kemiskinan bersifat multidimensional sehingga sangat berguna untuk digunakan sebagai pisau analisis dalam mendefinisikan kemiskinan dan merumuskan kebijakan pengentasan kemiskinan. Dimensi kemiskinan menyangkut aspek ekonomi, politik dan sosial-psikologis. Secara ekonomi, kemiskinan dapat dapat

\footnotetext{
${ }^{6}$ Diah Lukita Sari, \& al, W akaf Tunai: www. ekonomi-syariah.com. diakses pada 5 Mei 2008.

7 Edi Suharto, Membangun M asyarakat Memberdayakan Rakyat: Kajian Strategis Pembangunan Kesejahteraan Sosial \& Pekerjaan Sosial, (Jakarta: PT.Refika Aditama, 2006), hlm. 131

8 Dalam pengentasan kemiskinan salah satunya diperlukan orang yang peduli dan mampu secara ekonomi. Karena orang kaya (mampu) mempunyai kemampuan menepis sebagian faktor kemiskinan, memperbaiki, dan mengangkat martabat mereka, seperti mengurangi pengangguran dengan memberikan pekerjaan dan kebaikan bagi fakir, mengubur kebodohan dengan memberi infak untuk proses belajar mengajar, mengajarkan cara-cara usaha, dan menanamkan pendidikan untuk bekerja, konsisten dan jujur. Khafallah, M asyarakat M uslim Ideal, hlm. 105
} 
Rudy Haryanto

didefinisikan sebagi kekurangan sumberdaya yang dapat digunakan untuk memenuhi kebutuhan hidup dan meningkatkan kesejahteraan sekelompok orang. Secara politik, kemiskinan dapat dilihat dari tingkat akses terhadap kekuasaan (power). Kemiskinan secara sosialpsikologis menunjuk pada kekrangan jaringan dan struktur sosial yang mendukung dalam mendapatkan kesempatan-kesempatan peningkatan produktivitas. ${ }^{9}$

Terdapat banyak sekali teori dan pendekatan dalam memahami kemiskinan. Namun bila disederhanakan, setidaknya terdapat dua paradigma atau teori besar (grand theory) mengenai kemiskinan, yakni paradigma neo-liberal ${ }^{10}$ dan sosial demokrat ${ }^{11}$ yang memandang kemiskinan dari kacamata struktural dan individual. Pandangan ini kemudian menjadi basis dalam menganalisis kemiskinan maupun merumuskan kebijakan dan program-program anti kemiskinan.

Pandangan Neo-Liberal terhadap kemiskinan, landasan teorinya adalah individual, konsepsi dan Indikator kemiskinannya adalah kemiskinan absolute. Sedangkan penyebab kemiskinan, menurutnya adalah kelemahan dan pilihan-pilihan individu; lemahnya pengaturan pendapatan; dan lemahnya kepribadian (malas, pasrah, bodoh). Strategi penanggulangan kemiskinan ditempuh melalui penyaluran pendapatan kepada orang miskin secara selektif; member pelatihan ketrampilan pengelolaan keuangan. Prinsipnya adalah residual dan dukungan yang saling menguntungkan (mutual

9 Baca Suharto, M embangun M asyarakat, hlm. 133-135

10 Teori neo-liberal berakar pada karya politik klasik yang ditulis oleh Thomas Hobbes, John Lodk dan John Stuart Mill yang intinya menyerukan bahwa komponen penting dari sebuah masyarakat adalah kebebasan individu. Dalam bidang ekonomi, karya monumental Adam Smith, the W ealth of $\mathrm{N}$ ati on (1776), dan Frederidk Hayek, The R oad to Serfdom (1944), dipandang sebagai rujukan kaum neo-liberal yang mengedepankan azas laissez faire, sebagai ide yang mengunggulkan "mekanisme pasar bebas" yang terkenal dengan lima prinsip dasarnya. Lebih jelas baca T. May Rudy, Ekonomi Politik Internasional: Peran Domestik Hingga Ancaman Globalisasi, (Jakarta: Nuansa, 2007), hlm.117-118 dan Suharto, M embangun M asyarakat, hlm. 138.

11 Teori ini berpijak pada analisis Karl Marx (1818-1883) dan Frederick Engels (182018950, sebagai pendukung teori sosial demokrat yang mengedepankan nilai kamanusian. Dalam arti bahwa manusialah ukuran segala hal dan bahwa segala upaya sosial haruslah diukur dengan kriteria apakah itu mengembangkan pribadi manusia atau bukan. Lebih jelas baca Deliarnov, Perkembangan Pemikiran Ekonomi, (Jakarta: Raja Grafindo, 1997), hlm. 52 dan Suharto, M emban gun M asyarakat, hlm. 140 
aid). ${ }^{12}$ Dengan kata lain, para pendukung neo-liberal berargumen bahwa kemiskinan merupakan persoalan individual yang disebabkan oleh kelemahan-kelemahan dan atau pilihan-pilihan individu yang bersangkutan. Kemiskinan akan hilang dengan sendirinya jika kekuatan-kekuatan pasar diperluas sebesar-besarnya dan pertumbuhan ekonomi dipacu setinggi-tingginya. Secara langsung, strategi penaggulangan kemiskinan harus bersifat "residual", sementara, dan hanya melibatkan keluarga, kelompok-kelompok swadaya atau lembaga-lembaga keagamaan. Peran negara hanyalah sebagai "penjaga malam" yang baru boleh ikut campur manakala lembaga-lembaga di atas tidak mampu lagi menjalankan tugasny. Penerapan program-program structural adjustment, seperti Program Jaringan Pengaman Sosial atau JPS, di beberapa negara merupakan contoh kongkrit dari pengaruh neo-liberal dalam bidang penanggulangan kemiskinan ini. Kaum neo-liberal memandang bahwa strategi penanganan kemiskinan yang melembaga seperti konsep sosial demokrat merupakan tindakan yang tidak ekonomis dan menyebabkan ketergantungan.

Sedangkan pandangan sosial demokrat terhadap kemiskinan; Iandasan teorinya adalah struktural. Konsepsi dan Indikator kemiskinannya adalah kemiskinan relatif. Penyebab kemiskinan, menurutnya, adalah ketimpangan struktur ekonomi dan politik serta ketidakadilan sosial. Strategi penanggulangan kemiskinan ditempuh melalui enyaluran pendapatan dasar secara universal; perubahan fundamental dalam pola-pola pendistribusian pendapatan melalui intervensi negara. Prinsipnya adalah institusional, redistribusi pendapatan vertikal dan horizontal; aksi kolektif.13 Keyakinan yang berlebihan tehadap keunggulan mekanisme pasar dan pertumbuhan ekonomi yang secara alamiah dianggap akan mampu mengatasi kemiskinan dan ketidakdilan sosial mendapat kritik dari kaum sosial demokrat. Teori sosial demokrat memandang bahwa kemiskinan bukanlah persoalan individual, melainkan struktural. Kemiskinan disebabkan oleh adanya ketidakadilan dan ketimpangan dalam masyarakat akibat

12 Lebih jelas baca Rudy, Ekonomi Politik Internasional, hlm. 119-121 dan Suharto, M embangun M asyarakat, hlm. 139.

13 Lebih jelas baca Dawam Rahardjo, Kritik Terhadap M arxisme dan M arxisme sebagai K ritik T erhadap Pembangun an K apitalis, D alam E sei-E sei E konomi P olitik, (Jakarta: LP3ES, 1983), hlm. 100-106 dan Suharto, M embangun M asyarakat, hlm. 140-142 
Rudy Haryanto

tersumbatnya akses-akses kelompok tertentu terhadap berbagai sumber-sumber kemasyarakatan. Teori yang berporos pada prinsipprinsip ekonomi campuran (mixed economy) dan majemen ekonomi Keynesian ini, muncul sebagai jawaban terhadap depresi ekonomi yang terjadi pada tahun 1920-an dan awal 1930-an. Sistem negara kesejahteraan yang menekankan pentingnya manajemen dan pendanaan negara dalam pemberian pelayanan sosial dasar, seperti pendidikan, kesehatan, perumahan dan jaminan sosial, sangat dipengaruhi oleh pendekatan "ekonomi manajemen-permintaan" (demand-management economics) gaya Keynesian ini.

Meskipun tidak setuju sepenuhnya terhadap sistem pasar bebas, kaum sosial demokrat tidak memandang sistem ekonomi kapitalis sebagai evil. Bahkan kapitalis masih dipandang sebagai bentuk pengorganisasian ekonomi yang paling efektif. Hanya saja, kapitalisme perlu dilengkapi dengan sistem negara kesejahteraan agar lebih berwajah manusiawi.

Pendukung sosial demokrat berpendapat bahwa kesetaraan merupakan prasyarat penting dalam memperoleh kemandirian dan kebebasan. Pencapaian kebebasan hanya dimungkinkan jika setiap orang memiliki atau mampu menjangkau sumber-sumber, seperti pendidikian, kesehatan yang baik dan pendapatan yang cukup. Kebebasan lebih dari sekadar bebas dari pengaruh luar; melainkan pula bebas dalam menentukan pilihan-pilihan (choices). Dengan kata lain kebebasan berarti memiliki kemampuan (capabilities) untuk melakukan atau tidak melakukan sesuatu. Misalnya, kemampuan memenuhi kebutuhan dasarnya, kemampuan menghindari kematian dini, kemampuan menghindari kekurangan gizi, kemampuan membaca, menulis dan berkomunikasi. Negara karenanya memiliki peranan dalam menjamin bahwa setiap orang dapat berpartisipasi dalam transaksi-transaksi kemasyarakatan yang memungkinkan mereka menentukan pilihan-pilihannya dan memenuhi kebutuhankebutuhannya.

Menurut pandangan sosial demokrat, strategi kemiskinan haruslah bersifat institusional (melembaga). Program-program jaminan sosial dan bantuan sosial yang dianut di AS, Eropa Barat, dan Jepang, merupakan contoh strategi anti kemiskinan yang diwarnai oleh teori sosial demokrat. Jaminan sosial yang berbentuk pemberian tunjangan pendapatan atau dana pensiun, misalnya, dapat 
meningkatkan kebebasan karena dapat menyediakan penghasilan dasar dengan mana orang akan memiliki kemampuan (capabilities) untuk memenuhi kebutuhan dan menentukan pilihan-pilihannya (choices). Sebaliknya, ketiadaan pelayanan dasar tersebut dapat menyebabkan ketergantungan (dependency) karena dapat membuat orang tidak memiliki kemampuan dalam memenuhi kebutuhan dan menentukan pilihan-pilihannya.

Pendukung sosial demokrat meyakini bahwa penangananan kemiskinan yang bersifat residual, beorientasi proyek jangka pendek, justru merupakan strategi yang hanya menghabiskan dana saja karena efeknya juga singkat, terbatas dan tidak berwawasan pemberdayaan dan keberlanjutan. Apabila kaum neo-liberal melihat bahwa jaminan sosial dapat menghambat "kebebasan", kaum sosial demokrat justru meyakini bahwa ketiadaan sumber-sumber finansial yang mapan itulah yang justru dapat menghilangkan "kebebasan", karena membatasi dan bahkan menghilangkan kemampuan individu dalam menentukan pilihan-pilihannya (choices).

Di sisi lain, Badan Pusat Statistik dan Departemen Sosial RI mendefinisikan kemiskinan adalah ketidakmampuan individu dalam memenuhi kebutuhan dasar minimal untuk hidup layak. ${ }^{14}$ Kemiskinan merupakan sebuah kondisi yang berada di bawah garis nilai standar kebutuhan minimum, baik untuk makanan dan non makanan, yang disebut garis kemiskinan (poverty line) atau batas kemiskinan (poverty threshold). Garis kemiskinan adalah sejumlah rupiah yang diperlukan oleh setiap individu untuk dapat membayar kebutuhan makanan setara 2100 kilo kalori per orang per hari dan kebutuhan non-makanan yang terdiri dari perumahan, pakaian, kesehatan, pendidikan, transportasi, serta aneka barang dan jasa lainnya. 15

Kemiskinan pada umumnya didefinisikan dari segi pendapatan dalam bentuk uang ditambah dengan keuntungankeuntungan non-material yang diterima oleh seseorang. Secara luas kemiskinan meliputi kekurangan atau tidak memiliki pendidikan, keadaan kesehatan yang buruk, kekurangan transportasi yang

14 Badan Pusat Statistik dan Departemen Sosial RI., Penduduk Fakir M iskin Indonesia, (Jakarta: BPS, 2002), hlm. 3

$15 \mathrm{lbid}$ 
Rudy Haryanto

dibutuhkan oleh masyarakat.16 Fakir miskin adalah orang yang sama sekali tidak mempunyai kemampuan untuk memenuhi kebutuhan pokok yang layak bagi kemanusiaan atau orang yang mempunyai sumber mata pencaharian tetapi tidak memenuhi kebutuhan pokok yang layak bagi kemanusiaan. ${ }^{17}$

Kemiskinan adalah ketidaksamaan kesempatan untuk mengakumulasikan basis kekuasaan sosial. Basis ke saan sosial meliputi: (a) Modal produktif atau asset (tanah, perumahan, alat produksi, kesehatan), (b) Sumber keuangan (pekerjaan, kredit), (c) Organisasi sosial dan politik yang dapat digunakan untuk mencapai kepentingan bersama (koperasi, partai politik, organisasi sosial), (d) Jaringan sosial untuk memperoleh pekerjaan, barang, dan jasa, (e) Pengetahuan dan keterampilan, dan (f) Informasi yang berguna untuk kemajuan hidup.18

Kemiskinan memiliki berbagai dimensi ${ }^{19}$ :

Ketidakmampuan memenuhi kebutuhan konsumsi dasar (pangan, sandang dan papan); (2) Tidak adanya akses terhadap kebutuhan hidup dasar lainnya (kesehatan, pendidikan, sanitasi, air bersih dan transportasi); (3) Tidak adanya jaminan masa depan (karena tiadanya investasi untuk pendidikan dan keluarga); (4) Kerentanan terhadap goncangan yang bersifat individual maupun missal; (5) Rendahnya kualitas sumberdaya manusia dan keterbatasan sumber alam; (6) Tidak dilibatkannya dalam kegiatan sosial masyarakat; (7) Tidak adanya akses terhadap lapangan kerja dan mata pencaharian yang berkesinambungan; (8) Ketidakmampuan untuk berusaha karena cacat fisik maupun mental; (9) Ketidakmampuan dan ketidakberuntungan soaial (anak terlantar, wanita korban kekerasan rumah tangga, janda miskin, kelompok marjinal dan terpencil).20

Ketidakmampuan dan ketidakberuntungan sosial (anak telantar, wanita korban tindak kekerasan rumah tangga, janda miskin, kelompok marjinal dan terpencil) juga termasuk dalam kreteria

\footnotetext{
16 Edi Suharto, et al., Kemiskinan dan Keberfungsian Sosial: Studi Kasus Rumah Tangga $M$ iskin di Indonesia, (Bandung: STKSPress), 2004

17 Ibid., BPS dan Depsos, Pendudu k Fakir M iskin, hIm. 5

18 Suharto, et al., Kemiskinan, hlm. 6

$19 \mathrm{lbid}$

20 Suharto, M embangun M asyarakat, hlm. 132
} 
kemiskinan.21 Apabila keadaan ini tidak diperhatikan oleh pemerintah maka sudah jelas si miskin selamanya penuh dengan ketidak berdayaan. Untuk itu sudah seharusnya pemerintah menerapkan sistem negara kesejahteraan (welfare state) yang dapat melindungi dan menjamin kehidupan dasar warganya terhadap kondisi-kondisi yang memburuk yang tidak mampu ditangani oleh dirinya sendiri. Hal ini di karenakan kelangsungan hidup individu dalam situasi ini seringkali tergantung pada keluarga yang secara bersama-sama dengan jaringan sosial membantu para anggotanya dengan pemberian bantuan keuangan, tempat tinggal dan bantuanbantuan mendesak lainnya.

\section{Strategi Pengentasan Kemiskinan}

Strategi pengentasan kemiskinan bisa di mulai dari kebijakan pemerintah (yang sifatnya top down) sehingga elemen masyarakat tinggal mendukung kebijakan tersebut. Dalam pembangunan berkelanjutan yang dicanangkan pemerintah harus menjadi acuan dalam melaksanakan pembangunan disegala bidang. Didalam acauan tersebut ada klausal tentang pengentasan kemiskinan, untuk itu sudah seharusnya bahwa pemerintah telah membuat komitmen nasional untuk memberantas kemiskinan dalam rangka pelaksanaan pembangunan berkelanjutan, dimana pemerintah dan semua perangkat negara bersama dengan berbagai unsur masyarakat memikul tanggungjawab utama untuk mewujudkan pembangunan berkelanjutan dan sekaligus pengentasan kemiskinan.

Strategi yang lain adalah dengan memberdayakan masyarakat yang mempunyai kepedulian untuk mengentaskan kemiskinan. Karena sifatnya bottom up yang anggota dan dananya berasal dari masyarakat, maka sifatnya adalah sosial partisan yang dilakukan oleh para pekerja sosial. Pekerjaan sosial adalah profesi pertolongan kemanusiaan yang fokus utamanya untuk membantu orang agar dapat membantu dirinya sendiri. Dalam proses pertolongannya,

\footnotetext{
${ }^{21}$ Suharto, et al., Kemiskinan, hlm. 7-8
} 
Rudy Haryanto

pekerjaan sosial berpijak pada nilai, pengetahuan dan keterampilan profesional yang mengedepankan prinsip keberfungsian sosial.22

Konsep keberfungsian sosial pada intinya menunjuk pada kapabilitas individu, keluarga atau masyarakat dalam menjalankan peran-peran sosial di lingkungannya. Konsepsi ini mengedepankan nilai bahwa klien adalah subyek pembangunan; bahwa klien memiliki kapabilitas dan potensi yang dapat dikembangkan dalam proses pertolongan, bahwa klien memiliki dan atau dapat menjangkau, memanfaatkan, dan memobilisasi asset dan sumber-sumber yang ada di sekitar dirinya.

Sesuai dengan konsepsi mengenai keberfungsian sosial, strategi penanganan kemiskinan pekerjaan sosial terfokus pada peningkatan kemampuan orang miskin dalam menjalankan tugastugas kehidupan sesuai dengan statusnya. Karena tugas-tugas kehidupan dan status merupakan konsepsi yang dinamis dan multiwajah, maka intervensi pekerjaan sosial senantiasa melihat sasaran perubahan (orang miskin) tidak terpisah dari lingkungan dan situasi yang dihadapinya. Prinsip ini dikenal dengan pendekatan "person-inenvironment dan person-in-situation".

Pada pendekatan pertama, pekerja sosial melihat penyebab kemiskinan dan sumber-sumber penyelesaian kemiskinan dalam kaitannya dengan lingkungan dimana si miskin tinggal, baik dalam konteks keluarga, kelompok pertemanan (pœr group), maupun masyarakat. Penanganan kemiskinan yang bersifat kelembagaan (institutional) biasanya didasari oleh pertimbangan ini. Beberapa bentuk PROKESOS yang telah dan sedang dikembangkan oleh Depsos dapat disederhanakan menjadi: (1) Pemberian pelayanan dan rehabilitasi sosial yang diselenggarakan oleh panti-panti sosial; (2) Program jaminan, perlindungan dan asuransi kesejahteraan sosial. ${ }^{23}$

Pendekatan kedua, yang melihat si miskin dalam konteks situasinya, strategi pekerjaan sosial berpijak pada prinsip-prinsip individualisation dan self-determinism yang melihat si miskin secara individual yang memiliki masalah dan kemampuan unik. Program anti kemiskinan dalam kacamata ini disesuaikan dengan kejadian-

22 Edi Suharto, Pembangunan, Kebijakan Sosial dan Pekerjaan Sosial: Spektrum Pemikiran, (Bandung: Lembaga Studi Pembangunan STKS (LSP-STKS), 1997)

23 Suharto, M embangun M asyarakat, hlm. 151 
kejadian dan atau masalah-masalah yang dihadapinya. PROKESOS penanganan kemiskinan (yang pada prinsipnya memadukan pendekatan neo-liberal dan sosial demokrat ini) dapat dikategorikan kedalam beberapa strategi: (1) Strategi kedaruratan. Misalnya, bantuan uang, barang dan tenaga bagi korban bencana alam; (2) Strategi kesementaraan atau residual. Misalnya, bantuan stimulan untuk usaha-usaha ekonomis produktif; (3) Strategi pemberdayaan. Misalnya, program pelatihan dan pembinaan keluarga muda mandiri, pembinaan partisipasi sosial masyarakat, pembinaan anak dan remaja; (4) Strategi "penanganan bagian yang hilang". Strategi yang oleh Caroline Moser disebut sebagai "the missing piece strategy" ini meliputi program-program yang dianggap dapat memutuskan rantai kemiskinan melalui penanganan salah satu aspek kunci kemiskinan yang kalau "disentuh" akan membawa dampak pada aspek-aspek lainnya. Misalnya, pemberian kredit, program KUBE atau Kelompok Usaha Bersama. ${ }^{24}$

Mencermati beberapa paradigmatik penanggulangan kemiskinan diatas, ada strategi yang harus dilakukan untuk mengatasi kemiskinan supaya tepat sasaran yaitu: Pertama, karena kemiskinan bersifat multidimensional, maka program pengentasan kemiskinan seyogyanya juga tidak hanya memprioritaskan aspek ekonomi tapi memperhatikan dimensi lain. Dengan kata lain, pemenuhan kebutuhan pokok memang perlu mendapat prioritas, namun juga harus mengejar target mengatasi kemiskinan nonekonomik. Strategi pengentasan kemiskinan hen-daknya diarahkan untuk mengikis nilai-nilai budaya negatif seperti apatis, apolitis, fatalistik, ketidakberdayaan, dan sebagainya. A pabila budaya ini tidak dihilangkan, kemiskinan ekonomi akan sulit untuk ditanggulangi. Selain itu, langkah pengentasan kemiskinan yang efektif harus pula mengatasi hambatan-hambatan yang sifatnya struktural dan politis.

Kedua, untuk meningkatkan kemampuan dan mendorong produktivitas, strategi yang dipilih adalah peningkatan kemampuan dasar masyarakat miskin untuk meningkatkan pendapatan melalui langkah perbaikan kesehatan dan pendidikan, peningkatan

24 Ibid. 
Rudy Haryanto

keterampilan usaha, teknologi, perluasan jaringan kerja (networking), serta informasi pasar.

Ketiga, melibatkan masyarakat miskin dalam keseluruhan proses penanggulangan kemiskinan, mulai dari perencanaan, pelaksanaan, pengawasan, dan evaluasi, bahkan pada prosespengambilankeputusan.

Keempat, strategi pemberdayaan. Kelompok agrarian populism yang dipelopori kelompok pakar dan aktivis Lembaga Swadaya Masyarakat, menegaskan, masyarakat miskin adalah kelompok yang mampu membangun dirinya sendiri jika pemerintah mau memberi kebebasan bagi kelompok itu untuk mengatur dirinya.

\section{Wakaf Tunai sebagai Solusi Pengentasan Kemiskinan}

Sebuah kondisi dimana daya tarik wakaf sudah mulai dilirik untuk pemberdayaan secara professional-produktif. Keprofesionalan yang dilakukan meliputi aspek: manajemen, SDM ke-N azhir-an, pola kemitraan usaha, bentuk benda wakaf yang tidak hanya berupa harta tidak bergerak seperti uang, saham, dan surat berharga lainnya, dukungan political will secara penuh seperti lahirnya UU No. 41 Tahun 2004 tentang wakaf.

Cast waqf yang diterjemahkan dengan wakaf tunai, namun kalau menilik objek wakafnya, yaitu uang, lebih tepat kiranya kalau cast waqf diterjemahkan sebagai wakaf uang. Wakaf tunai adalah wakaf yang dilakukan sesorang, kelompok orang, dan lembaga atau badan hokum dalam bentuk uang tunai. 25

Kebolehan wakaf tunai sudah diatur dalam UU No 41 tahun 2004 yang disahkan oleh DPR RI serta berdasarkan fatwa MUI Indonesia tanggal 11 Mei 2002 yang berbunyi : (1) Wakaf uang (cash wakaf) adalah wakaf yang dilakukan seseorang, kelompok orang, lembaga atau badan hukum dalam bentuk uang tunai; (2) Termasuk ke dalam pengertian uang adalah surat-surat berharga; (3) Waqaf uang hukumnya jawaz (boleh); (4) Wakaf uang hanya boleh disalurkan dan digunakan untuk hal-hal yang dibolehkan secara syar'i. Nilai pokok wakaf uang harus dijamin kelestariannya, tidak boleh dijual, dihibahkan dan atau diwariskan.26

25 Departemen Agama RI, Pedoman Pengelolaan W akaf Tunai, hlm. 3 26 Sari, W akaf T unai. 
Pengentasan Kemiskinan

Dengan diundangkannya UU No. 41 Tahun 2004, maka kedudukan wakaf menjadi sangat jelas dalam tatanan hukum nasional, tidak saja dari sisi hukum Islam (fiqh). Dengan krisis yang dialami oleh Indonesia, maka wakaf tunai ini dapat menjadi salah satu instrumen dalam program pengentasan kemiskinan. Karena dengan wakaf tunai arahnya adalah wakaf menjadi produktif dan hasilnya dapat dimanfaatkan untuk membantu masyarakat yang membutuhkan dan di bawah garis kemiskinan. Seseorang yang memiliki uang atau dana yang terbatas pun dapat melaksanakan wakaf tunai ini dengan kemampuannya.

Nah dengan demikian, wakaf tunai bisa dilakukan oleh siapapun meski dana yang dimiliki cukup terbatas. Karena wakaf tunai ini memberi jalan kepada kaum Muslim yang ingin berwakaf, meskipun ia bukan dari golongan aghniyâ' (orang kaya).

Dalam redaksi Undang-Undang Wakaf No. 41 tahun 2004, menyebutkan sebagai berikut: "Wakaf adalah perbuatan hukum seseorang atau kelompok orang atau badan hukum yang memisahkan sebagian dari benda miliknya dan melembagakannya untuk selamalamanya guna kepentingan ibadat atau keperluan umum lainnya sesuai dengan ajaran agama Islam." 27

Landasan hukum wakaf tunai di Indonesia antara lain Surat Direktur Pengembangan Zakat dan Wakaf Depag, (terakhir) nomor Dt.1.II U5/ BA.03.2/ 2772/ 2002, tanggal 26 April 2002. Jadi, dapat disimpulkan bahwa benda apa saja sepanjang ia tidak dapat musnah setelah diambil manfaatnya, dapat diwakafkan. Uang pun termasuk benda yang dapat diwakafkan (wakaftunai), sepanjang uang tersebut dimanfaatkan sesuai dengan tujuan akad wakaf dan tidak habis atau musnah. Jadi uang dapat saja diwakafkan dengan mekanisme membelanjakan uang tersebut pada benda-benda yang memiliki sifat tidak musnah. 28

27 Menurut istilah syara' wakaf adalah menahan harta yang mungkin diambil manfaatnya tanpa menghabiskan atau merusakan bendanya dan digunakan untuk kebaikan. Adijani al-Alabij, Perwakafan Tanah di Indonesia: Dalam Teori dan Praktek, (Jakarta: Rajawali Pers, 1989), hlm. 23. Sedangkan definisi diatas merupakan definisi dalam Kompilasi Hukum Islam di Indonesia BUKU III, BAB I Pasal 215 ayat 1. Lihat A bdurrahman, Kompilasi Hukum Islam di Indosesia, (Jakarta: Akademika Presindo, 2004), hlm. 165.

28 Sari, W akaf T unai. 
Rudy Haryanto

Urgensi wakaf tunai (cash waqf ) adalah dengan cara menjadikan uang tersebut sebagai modal usaha kemudian menyalurkan keuntungannya sebagai wakaf. A dapun manfaat utama wakaf tunai adalah: (a) Seseorang yang memiliki dana terbatas sudah bisa mulai memberikan dana wakafnya tanpa harus menunggu menjadi tuan tanah terlebih dahulu; (b) Melalui wakaf uang, aset-aset wakaf yang berupa tanah-tanah kosong bisa mulai dimanfaatkan dengan pembangunan gedung atau diolah untuk lahan pertanian; (c) Dana wakaf tunai juga bisa membantu sebagian lembaga-lembaga pendidikan Islam; (d) Umat Islam dapat lebih mandiri dalam mengembangkan dunia pendidikan tanpa harus terlalu tergantung pada anggaran pendidikan negara yang memang semakin lama semakin terbatas.

Sasaran Wakaf Tunai, para praktisi pengelola wakaf masih menjadikan pendapat M. Abdul Manan, pakar ekonomi Islam dari Bangladesh ini, sebagai rujukan penting. Pertama, kemanfaatan bagi kesejahteraan pribadi (dunia-akhirat). Renungannya, saat lahir seseorang miskin, mati pun kembali miskin dan semua berakhir kecuali tiga perkara yang salah satunya amal jariyah. Maka wakaf tunai dapat menjadi sedekah jariyah yang berperan mengantar kesejahteraan dunia-akhirat seseorang. Kedua, kemanfaatan bagi kesejahteraan keluarga (dunia akhirat). Ini bisa menjadi wujud tanggungjawab sosial kita kepada orangtua, istri, anak-anak atau anggota keluarga yang lain. Ketiga, pembangunan sosial. Wakaf tunai bisa membuka banyak peluang untuk membantu masyarakat. Dari profit wakaf tunai, seseorang dapat membantu memberikan bantuan yang berharga bagi pendirian atau pun operasionalisasi lembagalembaga pendidikan maupun masjid. Wakaf tunai dapat pula membantu terlaksananya proyek-proyek pendidikan, riset, keagamaan, kesejahteraan sosial, pengobatan dan perawatan kesehatan bagi kaum dhuafa, dan penghapusan kemiskinan. Wakaf tunai juga bisa dimanfaatkan untuk beasiswa pelajar dan atau mahasiswa. Bisa disimpulkan, kemanfaatan wakaf tunai bersifat abadi, berbeda dengan derma temporer, wakaf tunai bisa direncanakan secara baik dan bersifat abadi sehingga banyak kelompok masyarakat dapat menikmati hasilnya secara terusmenerus. Keempat, membangun masyarakat sejahtera: jaminan sosial bagi si miskin dan jaminan keamanan sosial bagi si kaya. Wakaf tunai 
dalam tahap yang makin baik, menjadi wahana terciptanya kepedulian dan kasih sayang si kaya terhadap si miskin, sehingga tercipta hubungan harmonis dan kerjasama yang baik. Wakaf tunai bisa diandalkan menebar manfaat di bidang ekonomi dan sosial bagi masyarakat secara keseluruhan. ${ }^{29}$

Dalam hal pengelolaan wakaf, perlu ada standar pengelolaan yang yang dibakukan agar dana yang dkumpulkan dapat diberdayakan secara maksimal. Dalam hal ini peran perbankan atau Lembaga keuangan Syarî'ah sangat di perlukan. LKS dapat berperan sebagi nazhir yang mengumpulkan, meyalurkan dan mengelola dana wakaf. Dalam rangka mendukung keberhasilan pengembangan aspek produktif dari dana wakaf tunai, perlu diarahkan model pengelolaan dana tersebut kepada sector usaha yang produktif dengan lembaga usaha yang memiliki reputasi yang baik. Seperti menjalin kerjasama (networking) dengan perusahan modal ventura. Kerjasama ini juga dimaksudkan untuk mengaplikasikan model pembiayaan mudlarabah maupun musyarakah.

Difungsikanya perbankan Syari'ah sebagai nazhir setidaknya memiliki beberapa keunggulan yang diharapkan dapat mengoptimalkan operasionalisasi harta (dana) wakaf, yaitu: (1) Memililki jaringan kantor; (2) Kemampuan sebagai fund manager; (3) Pengalaman, jaringan-jaringan informasi dan peta distribusi; dan (4) Memiliki citra positif.30 Dengan melibatkan lembaga keuangan Syari'ah dalam pengelolaan wakaf tunai, maka selain produktif, wakaf akan bias diinvestasikan ke dalam berbagai jenis investasi yang menuntungkan. Dengan demikian, masyarakat yang akan merasakan manfaat dari hasil dana wakaf semakin banyak. ${ }^{31}$

Hasil pengelolaan dana wakaf tunai dapat dimanfaatkan secara lebih luas dalam rangka kesejahteraan masyarakat banyak. Adapun variable kesejahteraan masyarakat itu sendiri sangat luas. Variable-variabel tersebut meliputi pendidikan, kesehatan, pelayanan sosial, dan pengembangan ekonomi melalui pemberdayaan usaha kecil dan menengah.

29 M. Abdul Manan. Sertifikat Wakaf Tunai, Sebuah Inovasi Keuangan Islam, (Jakarta: CIBER dan PKTTI UI, 2002).

30 Departemen Agama RI, Pedoman Pengelolaan, hlm. 46

31 Ibid., hlm. 48 
Rudy Haryanto

\section{Pengentasan Kemiskinan melalui Pendekatan Wakaf Tunai dalam Perspektif Ekonomi Mikro dan Makro}

Trend perkembangan global menunjukan kecenderunagn pelaksanaan satu sistem yaitu system pasar atau system kapitalis. Terdapat banyak kelemahan dalam system kapitalis tersebut. 32 System Ekonomi Syari'ah berbeda dengasistem ekonomi konvensioanl dalam banyak hal. System Ekonomi Syari'ah di samping mampu mengatasi kelemahan-kelemahan yang ada, juga bias melepaskan ketergantungan ekonomi yang selama ini mengancam kemandirian bangsa. 33

Untuk mengatasi hal tersebut, wakaf yang merupakan salah satu unsure dalam lembaga-lembaga Ekonomi Islam yang berasal dari kegiatan sector volunter. Ciri khas daripada kegiatan wakaf dari sudut ekonomi adalah kegiatan investasi dan bukan bukan konsuntif. Untuk itu perlu dipersiapkan berbagai prasarana serta sarana yang mendukung pemberdayaan lembaga wakaf baik yang bergerak dalam kegiatan wakaf harta tak bergerak maupun harta bergerak.34

Penanggulangan kemiskinan dapat diibaratkan dengan analogi ikan dan kail. Sering dikatakan bahwa memberi ikan kepada si miskin tidak dapat menyelesaikan masalah. Si miskin akan menjadi tergantung. Kemudian, banyak orang percaya memberi kail akan lebih baik. Si miskin akan lebih mandiri. Benarkah?

A nalogi ini perlu diperluas. Memberi kail saja ternyata tidak cukup. Meskipun orang punya kail, kalau ia tidak memiliki cara mengail ikan tentunya tidak akan memperoleh ikan. Pemberian keterampilan (capacity building) kemudian menjadi kata kunci dalam proses pemberdayaan masyarakat. Setelah orang punya kail dan memiliki keterampilan mengail, tidak dengan serta merta ia dapat mengumpulkan ikan, jikalau lautan, sungai dan kolam dikuasai kelompok elite. Karenanya, penanganan kemiskinan memerlukan pendekatan makro kelembagaan. Perumusan kebijakan sosial adalah

32 Manan. Sertifikat W akaf Tunai, hIm. 100

33 Djunaidi dan al-Asyiar, M enuju E ra W akaf Produktif, hlm. 81-82

34 Ibid., hlm. 90-91 
salah satu piranti penciptaan keadilan yang sangat penting dalam mengatasi kemiskinan. 35

Globalisasi sangat dipengaruhi oleh pemikiran kapitalisme yang mempunyai pandangan filsafat ekonomi klasik, tokoh yang sangat berpengaruh dalam pandangan ini adalah Adam Smith dan dua pemikir yang tidak kalah pentingnya dalam pembentukan pandangan ini, yaitu David Ricardo dan Thomas Robert Maltus serta sangat dielu-elukan oleh dua pemikir pada jaman sekarang, yaitu Francis Fukuyama dan Thomas L. Friedman yang memberikan tesisnya tentang globalisasi, liberalisme, privatisasi, dan kapitalisme sebagai akhir sejarah. ${ }^{36}$

Realitas yang terjadi adalah Indonesia merupakan dari negara dunia ketiga yang belum mampu membendung pasar bebas dan hal tersebut merupakan suatu keniscayaan serta sewaktu-waktu akan siap membinasakannya. Masalah pengangguran dan kemiskinan merupakan masalah klasik yang selalu melekat dan menjadi ciri khas negara Indonesia, masalah ini juga merupakan masalah yang paling klimaks dihadapi oleh negara ini, sebab proses penyelenggaraan negara yang begitu panjang akan membayangkan adanya pengurangan angka pengangguran dan kemiskinan, karena hal tersebut merupakan mainstream dari sebuah pembangunan. Sehingga tiak mengherankan jika angka kemiskinan setiap tahun semakin meningkat.

Konsep yang amat dekat dengan konsep kemiskinan adalah impoverishment (hal-hal menyebabkan seseorang atau sesuatu menjadi lebih miskin). Proses impoverisment adalah sebuah proses aktif menghilangkan akses dan hak-hak dasar yang secara sistematik direproduksi dan diciptakan oleh sejumlah mekanisme global seperti kerusakan lingkungan hidup, kehancuran sumberdaya rakyat,inflasi, pengangguran dan politik utang luar negeri. Proses inilah yang

35 Adiwarman A. Karim, Ekonomi M ikro Islami, (Jakarta: PT. Raja Grafindo Persada, 2007), hlm. 8

36 A kan tetapi paham kapitalis tersebut bertentangan dengan konsep dalam ekonomi Islam, karena Islam sangat menentang setiap aktivitas ekonomi yang bertujuan melakukan penimbunan kekayaan atau pengambilan keuntungan yang tidak layak dari kesulitan orang lain atau penyalahgunaannya. Adiwarman Azwar Karim, Sejarah Pemikiran Ekonomi Islam, (Jakarta: PT. raja Grafindo Persada, 2006), hlm. 29 
Rudy Haryanto

dikenal sebagai proses pelemahan ekonomi, ekologi, sosial, politik dan kebudayaan.

Dengan melihat realitas permasalahan yang ada dalam upaya pengentasan kemiskinan melalui proses pemberdayaan ekonomi mikro sebagai pilar pembangunan, maka strategi-strategi yang digunakan adalah sebagai berikut:37 Pertama, adanya kerjasama yang mutalisme antara pemerintah, swasta serta elemen masyarakat menengah (LSM, A kademisi, Wartawan, Profesional, dlI) untuk bisa mendorong ekonomi mikro untuk bisa menjadi salah satu tembok dalam menghindari kemiskinan. Strategi itu bisa dilakukan apabila ketiga elemen tersebut memiliki kesamaan visi dan misi dalam pembangunan, misalnya dalam pembinaan pemberdayaan ekonomi mikro melalui pemberdayaan wakaf tunai.

Kedua, pemerintah dan MUI harus bisa menciptakan regulasi yang pro terhadap ekonomi mikro, misalnya dalam era otonomi daerah ini pemerintah daerah setempat yang sangat mengedepankan peraturan daerah, maka peraturan daerah sudah harus melibatkan MUI setempat untuk menghasilakan kebijakan yang bisa mendorong kekuatan ekonomi local baik dalam kebijakan Lembaga Keuangan Mikro maupun aplikasinya yang semuanya tentunya berorientasi terhadap pemberdayaan wakaf tunai, bukan malah sebaliknya mendorong ekonomi sebagian kelompok orang saja yang nota benenya dari kalangan ekonomi besar. Oleh karena itu jangan ada peraturan daerah yang mendorong resistensi masyarakat terhadap pemerintah daerah seperti penggusuran pedagang kaki lima tanpa memberikan solusi, yang saling menguntungkan antara kedua belah pihak, hal-hal tersebut harus di hindari oleh pemerintah daerah apabila ingin menciptakan kekuatan ekonomi mikro sebagai pilar untuk upaya dalam mengentaskan kemiskinan di daerah.

Ketiga, pemerintah, swasta, dan elemen masyarakat yang diwakili oleh LSM harus bisa membuat lembaga-lembaga keuangan mikro yang dananya bersumber dari wakaf tunai dari masyarakat sehingga lembaga keuangan mikro tersebut akan kuat serta mengedepankan distribusi keadilan dalam prosesnya. Hal tersebut

37 Michael P. Todaro, Pembangunan Ekonomi di D unia Ketiga, (Jakarta: Erlangga, 2000), hlm. 229 
supaya usaha mikro bisa terhindar dari rentenir yang nota benenya akan mengeksploitasi usaha mikro dengan bunga yang tinggi.

Keempat, perlunya dukungan baik material (berupa dana dengan wakaf tunai) maupun immaterial (peraturan dan kebijakan) dari penguasa, MUI, tokoh masyarakat dan Agama dan Lembaga Swadaya Masyarakat sehingga lembaga keuangan mikro bisa berkompetisi dengan lembaga keuangan yang informal dengan mengedepankan pelayanan yang pro terhadap usaha mikro, sehingga usaha mikro akan tertarik serta nyaman dalam melakukan pinjamannya, hal yang terpenting dan merupakan indikator pelayanan adalah proses pelayanan yang tidak berbelit-belit.

Kelima, adalah bagaimana elemen-elemen tersebut mempunyai komitmen dalam bekerjasama untuk bisa merealisasikan visi dan misi dalam melenyapkan kemiskinan yang kita hadapi ini.

Dalam Islam, wakaf sering disebut sebagai sumber asset yang member kemanfaatan sepanjang masa.38 Intitusi wakaf telah memainkan peran yang sangat penting dalam sejarah kaum muslim dalam membangun kesejahteraan rakyat. ${ }^{39}$ Sebab itu, sampai saat ini potensi wakaf sebagai sarana berbuat kebajikan bagi kepentingan masyarakat perlu dikelola dan diberdayakan secara masimal dalam ruang lingkup nasioanal. Wakaf tunai membuka peluang yang unik bagi penciptaan investasi di bidang ekonomi termasuk bidang keagamaan, pendidikan, dan pelayanan sosial. 40

Dengan peran tersebut diharapkan kemiskinan teratasi dengan focus merubah kemampuan orang miskin dalam menjalankan tugas-tugas kehidupan sesuai statusnya. Dan mengubah strukturstruktur sosial masyarakat yang tidak adil. Sehingga dari analog diatas bisa dikembangkan menjadi masyarakat tidak saja mempunyai kail tetapi juga harus mempunyai ketrampilan memancing. Tidak ada dominasi kepemilikan kolam ikan oleh kelompok-kelompok elite dalam masyarakat, sehingga masyarakat mempunyai kebebasan memancing. Dan masyarakat mampu memperluas atau disediakan akses pemasaran untuk menjual ikan hasil memancing tersebut. ${ }^{41}$

\footnotetext{
38 Departemen Agama RI, P edoman Pengelolaan, hlm. 94

39 Michael Dumper, W akat M uslimin di N egara Y ahudi, (Jakarta: Lentera, 1994), hlm. 1

40 Manan, Sertifikat W akaf T unai, hlm. 95

41 Suharto, M embangun M asyarakat, hlm. 150-151
} 
Rudy Haryanto

\section{Penutup}

Kemiskinan merupakan masalah kompleks yang tidak mudah diatasi. Namun, dengan pendekatan yang tepat, kemiskinan akan lebih mudah didekati. Penanggulangan kemiskinan memerlukan pemahaman mengenai dimensi dan pengukuran kemiskinan yang operasional. Setelah kemiskinan dapat dipotret secara akurat, strategi pengentasan kemiskinan dapat dikembangkan. Strategi tersebut sebaiknya menyentuh pendekatan langsung dan tidak langsung, mikro dan makro, yang dilakukan secara simultan dan berkelanjutan. Strategi yang belum diberdayakan secara optimal tetapi mempunyai peluang yang besar untuk mengentaskan kemiskinan tersebut adalah dengan mengaplikasikan wakaf tunai.

Wakaf tunai pada hakikatnya bukan merupakan instrumen baru. Praktik wakaf tunai telah dikenal lama dalam sejarah Islam. Pemerintah juga sudah memikirkan secara serius upaya untuk menggali potensi wakaf tunai ini. Hal ini dibuktikan telah disyahkannya UU No 41 Tahun 2004 tentang Wakaf sebagai payung hukum pelaksanaan wakaf tunai.

Wakaf tunai itu pada dasarnya bertujuan menghimpun dana abadi yang bersumber dari umat, yang kemudian dapat dimanfaatkan bagi sebesar-besarnya kepentingan dakwah dan masyarakat. Selama ini, masyarakat hanya mengenal wakaf dalam bentuk tanah dan bangunan. Sedangkan wakaf dalam bentuk uang belum tersosialisasi dengan baik. Padahal, wakaf tunai ini memberi kesempatan kepada setiap orang untuk bersadaqah jariyah dan mendapat pahala yang tidak terputus tanpa harus menunggu menjadi tuan tanah atau saudagar kaya. Orang bisa berwakaf hanya dengan membeli selembar sertifikat wakaf tunai yang diterbitkan oleh institusi pengelola wakaf (nadzir). Hal tersebut berbeda dengan zakat, di mana untuk menjadi muzakki, seseorang harus memenuhi sejumlah persyaratan yang di antaranya adalah hartanya harus melebihi nishab.

Dana wakaf yang terkumpul ini selanjutnya dapat digulirkan dan diinvestasikan oleh nadzir ke dalam berbagai sektor usaha yang halal dan produktif, sehingga keuntungannya dapat dimanfaatkan untuk pembangunan umat dan bangsa secara keseluruhan. Fakta pun telah menunjukkan bahwa banyak lembaga yang bisa bertahan 
dengan memanfaatkan dana wakaf, dan bahkan memberikan kontribusi yang signifikan bagi kaum muslim khususnya dalam membangun kesejahteraan rakyat. W allâh a'lam bi al-shawâb.

\section{D aftar Pustaka:}

A bdurrahman. Kompilasi H ukum Islam di Indosesia. Jakarta: A kademika Presindo, 2004.

Alabij, Adijani al-. Perwakafan Tanah di Indonesia: Dalam Teori dan Praktek. Jakarta: Rajawali Pers, 1989.

Badan Pusat Statistik dan Departemen Sosial RI. Penduduk Fakir M iskin Indonesia. Jakarta: BPS, 2002.

Deliarnov. Perkembangan Pemikiran Ekonomi. Jakarta: Raja Grafindo, 1997.

Departemen Agama RI, Pedoman Pengelolaan Wakaf Tunai. Jakarta: Direktorat Pemberdayaan Wakaf Direktorat Jendral Bimbingan Masyaratat Islam, 2007.

Djunaidi, Achmad dan Thobieb al-Asyiar. M enuju Era Wakaf Produktif. Depok: Mumtaz Publishing, 2007.

Dumper, Michael. Wakat M uslimin di N egara Y ahudi. Jakarta: Lentera, 1994.

Haq, Faishal dan Anam, Saiful. Hukum Wakaf dan Perwakafan di Indonesia. Pasuruan: GBI, 1993.

Karim, A diwarman Azwar. Ekonomi M ikro Islami. Jakarta: PT. Raja Grafindo Persada, 2007

Sejarah Pemikiran Ekonomi Islam. Jakarta: PT. Raja Grafindo Persada, 2006

Khalafallah, Muhammad Ahmad. M asyarakat M uslim Ideal. Jakarta: Insan Madani, 2008

Manan, M. Abdul. Sertifikat Wakaf Tunai, Sebuah Inovasi Keuangan Islam. Jakarta: CIBER dan PKTTI UI, 2002

Rahardjo, Dawam. Kemiskinan Sebagai Masalah Ekonomi, Dalam EseiEsei Ekonomi Politik. Jakarta: LP3ES, 1983. 
Rudy Haryanto

Rahardjo, Dawam. Kritik Terhadap M arxisme dan Marxisme sebagai Kritik Terhadap Pembangunan Kapitalis, Dalam Esei-Esei Ekonomi Politik, Jakarta: LP3ES, 1983.

Rudy, T. May. Ekonomi Politik Internasional: Peran Domestik Hingga A ncaman G lobalisasi . Jakarta: N uansa, 2007.

Sari, Diah Lukita. et al, Wakaf Tunai: www.ekonomi-syariah.com; diaskses pada 5 Mei 2008.

Suharto, Edi et al., Kemiskinan dan Keberfungsian Sosial: Studi Kasus Rumah Tangga M iskin di Indonesia, Bandung: STKSPress, 2004.

Suharto, Edi. Pembangunan, Kebijakan Sosial dan Pekerjaan Sosial: Spektrum Pemikiran. Bandung: Lembaga Studi Pembangunan STKS (LSP-STKS), 1997.

Suharto, Edi. M embangun M asyarakat M emberdayakan Rakyat: Kajian Strategis Pembangunan Kesejahteraan Sosial \& Pekerjaan Sosial. Jakarta: PT.Refika A ditama, 2006.

Todaro, Michael. P. Pembangunan Ekonomi di Dunia Ketiga. Jakarta: Erlangga, 2000. 